\title{
STRATEGI PENGUATAN PEMBANGUNAN MADURA YANG BERKELANJUTAN MELALUI PEMBERDAYAAN NILAI KEARIFAN LOKAL
}

\author{
Abd Hannan \\ Magister Sosiologi, Fakultas Ilmu Sosial dan Ilmu Politik, \\ Universitas Airlangga, Surabaya \\ hannan.taufiqi@gmail.com
}

\begin{abstract}
Being declared in 2015 in Rio De Janeiro, Brazil. development based Sustainable Development Goals (SDGs) has an aim to operate the development which is not only in progression but also in the orientation of maintenance of social area.Reaching the aim development based SDGs gives high response to universal development, emancipative, and participative that orientate to local wisdom value. This study focus on having an aim of analyzing on going Madura reinforcement through empowerment of local wisdom value. Several main issues become a focus of this analysis namely sustainable development concept, and the concept of local wisdom value. This study is descriptive study by library approach. The theory perspective of this study is development sociology theory. The finding of this study is about description concept and sustainable development theory; the explanation of local wisdom value in a system and social structure of Madura society; and descriptive analysis about sustainable development of Madura through empowerment of local wisdom value. Generally, this paper contributes of explaining the existence of local wisdom value in Madura development dynamic, and the explanation of social change of local society in sustainable development era.
\end{abstract}

Keywords: sustainable development, local wisdom value 


\begin{abstract}
Abstrak
Sejak pertama kali dideklarasikan pada tahun 2015 di Rio De Janeiro, Brasil, pembangunan berbasis Sustainable Development Goals (SDGs) memiliki tujuan menjalankan pembangunan yang tidak saja berkemajuan, namun juga berorintasi pada pemeliharaan lingkungan-sosial. Sebagai upaya mecapai tujuan tersebut, pembangunan SDGs memberi perhatian cukup besar terhadap pembangunan universal, emansipatif, dan partisipatif yang berasaskan nilai kearifan lokal. Studi ini secara khusus memiliki tujuan dalam hal mengkaji penguatan Madura berkelanjutan melalui pemberdayaan Nilai kearifan lokal. Beberapa issu utama yang menjadi fokus kajian ini meliputi; konsep pembangunan (berkelanjutan), serta konsep tentang nilai kearifan lokal. Kajian ini merupakan studi deskriptif melalui pendekatan kepustakaan. Adapun perspektif teori dalam kajian ini menggunakan teori Sosiologi Pembangunan. Temuan studi ini berisikan deskripsi konsep dan teori pembangunan (berkelanjutan); penjelasan mendalam tentang nilai kearifan lokal dalam sistem dan struktur sosial masyarakat Madura; serta analisis deskriptif mengenai pembangunan Madura berkelanjutan melalui pemberdayaan nilai kearifan lokal. Secara umum, penulisan paper ini memiliki sumbangsih besar dalam hal menjelaskan eksistensi nilai kearifan lokal dalam dinamika pembangunan masyarakat Maadura, serta penjelasan tentang perubahan sosial masyarakat setempat dalam era pembangunan Madura berkelanjutan.
\end{abstract}

Kata Kunci: pembangunan berkelanjutan, nilai kearifan lokal

\section{PENDAHULUAN}

Dalam beberapa tahun terakhir, term pembangunan berkelanjutan (SDGs) menjadi salah satu isu pembangunan yang berhasil mengundang perhatian besar banyak kalangan (Rahadian, 2016: 47). Negara-negaraduniayangtergabungdalam organisasi Perserikatan Bangsa-Bangsa (PBB) berusaha semaksimal mungkin menyelaraskan visi pembangunan negara mereka dengan rancangan pembangunan SDGs. Nampaknya, ada keyakinan dalam dirimereka, bahwa era pembangunanSDGs yang dewasa ini tengah bergulir adalah momentum tepat untuk menguatkan laju pertumbuhan dan pembangunan negara mereka.

Jika menengok aktivitas pembangunan era sebelumnya, yakni era milenium, Millennium Development Goals (MDGs), ada kekhawatiran cukup mendalam perihal nasib pembangunan dunia ke depan (Sulistyo dkk, 2010: 16). Kekhawatiran tersebut muncul ketika orientasi pembangunan MDGs, di satu sisi sekadar mengejar kepentingan ekonomis, dan di sisi lain cenderung mengabaikan nilai-nilai emansipatif, universalitas, dan ekosistem lingkungan. Sebagai akibatnya, kita menyaksikan pembangunan pada era MDGs berjalan tidak sehat, sehingga menyisakan banyak krisis sosial (Sulistyastuti, 2007: 41), mulai dari eksploitasi alam, kemiskinan, dan ketimpangan sosial yang cukup melebar.

Di Indonesia sendiri, problem sosial pembangunan era milenium, sempat mengundang kerisauan banyak kalangan. Pasalnya, tiga daridelapan program sasaran pembangunan milenium, sebagaimana telah dirumuskan oleh negara-negara dunia, terancam mengalami kegagalan. 
Kemungkinan kegagalan tersebut ditunjukkan oleh indikator angka kematian ibu yang masih tinggi, pencegahan HIV/ AIDS dan indikator tutupan lahan pada sektor kehutanan yang belum optimal (Sulistyo dkk, 2010: 16).

Kini, pasca diresmikannya pembangunan SDGs sebagai kelanjutan dari pembangunan MDGs, problem pembangunan Indonesia masih berkutat pada sektor permasalahan yang sama. Bahkan, berdasarkan data World Bank, Indonesia saat ini tengah mengalami persoalan besar menyangkut disparitas dan distribusi kekuasaan yang tidak merata. Instrumen pembangunan kita sejauh ini lebih berkepihakan pada kepentingan kelas sosial atas, atau kaum pemodal. Sebaliknya, masyarakat dengan status kelas sosial ekonomi menengah ke bawah tidak cukup mampu untuk menjangkaunya. Bahwa, 1 persen orang terkaya di Indonesia menguasai 45,5 persen kekayaan nasional dan 10 persen orang terkaya menguasai 75 persen kekayaan nasional (Republika/03/18).

Jika problem pembangunan skala nasional tersebut kita turunkan pada level yang lebih rendah, katakanlah level daerah, baik itu daerah provinsi, kota, atau kabupaten, maka di sini kita juga akan menemukan permasalahan yang relatif seragam. Bahwa tidak sedikit daerah yang proses pembangunannya mengalami masalah (Surtikanti, 2013: 20), karena dalam banyak hal agenda pembangunan mereka harus berbenturan dengan politik kebijakan yang tidak mengusung semangat universal. Dalam arti yang lain, tidak berkesesuaian dengan kebutuhan mereka sebagai bagian teritorial yang seharusnya otonom.

Dalam kerangka pemikiran inilah, berbagai sisi persoalan yang selama ini mengganjal pembangunan Pulau Madura sesungguhnya dapat dikaji dalam perspektif ini. Bahwa problem bangunan setempat, selain karena faktor kultural yang bersentuhan dengan mentalitas kebudayaan masyarakat, juga karena faktor struktural yang bermuara dari sistem pembangunan yang tidak berkesesuaian. Yakni, sebuah realitas pembangunan yang tidak berpihak pada kepentingan dan kebutuhan masyarakat Madura, pun tidak memiliki keselarasan dengan aspek sosiologis Kepulauan Madura sebagai daerah kepulauan. Sebagai faktanya, kita menyaksikan pembangunan Madura seoalah berjalan stagnan. Berdasarkan data pusat statistik Jawa Timur, empat daerah Madura, dari Bangkalan, Sampang, Pamekasan, dan Sumenep, hingga detik ini tercatat sebagai daerah termiskin di Jawa Timur (Jawa Pos, 18/07/17). Ironisnya, meski Pulau Madura memiliki potensi alam-sosial yang cukup kaya, nyatanya daerah Madura saat ini tercatat sebagai kantong kemiskinan Jawa Timur (Yamin dkk, 2013: 226).

Studi ini secara khusus akan mengkaji tentang Strategi Penguatan Pembangunan Madura Yang Berkelanjutan Melalui Pemberdayaan Nilai Kearifan Lokal. Terdapat dua isu krusial yang menjadi fokus permasalahan dalam penulisan ini. Pertama, isu pembangunan (berkelanjutan). Kedua, nilai kearifan lokal (Madura). Dalam upaya membuat penulisan paper ini lebih terfokus, maka pembahasan dua permasalahan di atas akan dijabarkan melalui pertanyaan seputar: apa yang dimaksud dengan pembangunan berkelanjutan (SDGs)? Kemudian, bagaimana menguatkan pembangunan Madura yang berkelanjutan melalui pemanfaatan 
dan pemberdayaan nilai-nilai daerah yang berkearifan lokal? Dua pertanyaan seputar pembangunan Madura di atas ditujukan untuk mendeskripsikan konsep pembangunan berkelanjutan. Penjelasan mendalam tentang pembangunan Madura berkelanjutan melalui strategi penguatan nilai kearifan lokal.

\section{METODE PENELITIAN}

Metode penelitian paper ini menggunakan metode kepustakaan. Metode kepustakaan atau yang terkenal dengan studi kepustakaan adalah metode yang menekankan pada penggunaan literatur sebagai sumber data utama. Istilah literatur di sini merujuk pada setiap kajian keilmuan yang memiliki relevansi dengan fokus masalah yang diangkat dalam peulisan ini (Wirartha, 2006: 150). Dalam kesempatan ini, penelusuran data melalui studi kepustakaan difokuskan pada tiga tema besar: konsep pembangunan (berkelanjutan), sosiokultur masyarakat Madura, dan konsep mengenai nilai kearifan lokal.

Dalam upaya memperoleh data yang objektif, maka studi kepustakaan dalam kajian ini lebih mengedepankan pembacaan data-data baru, khususnya yang bersumber dari hasil-hasil penelitian, baikitu dalam bentukskripsi, tesis, disertasi, dan jurnal penelitian. Sekian literatur yang memuat kajian seputar Madura, konsep pembangunan dalam perspektif yang luas, keduanya adalah tema-tema strategis yang akan banyak dituangkan dalam penulisan paper ini. Pembacaan tentang pembangunan dan dinamika sosio-kultur Madura dalam sudut pandang yang luas akan membuat sajian tulisan ini menjadi lebih kritis dan mendalam.

\section{HASIL DAN PEMBAHASAN Pembangunan: Sebuah Tinjauan Konseptual}

Dalam diskursus ilmu sosial, perbincangan tentang pengertian pembangunan menjadi salah satu tema yang banyak diperdebatkan. Hingga sekarang pun, perdebatan mengenai definisi pembangunan tidak kunjung terselesaikan. Hampir tidak ada satu pun disiplin keilmuan yang dapat memunculkan pengertian pembangunan melalui konsep dan pemikiran yang final. Itu menandakan, term pembangunan erat hubungannya dengan permasalahan dan perubahan sosial yang tidak saja kompleks, namun juga dinamis. Bahwa pembangunan adalah representasi gerak perubahan masyarakat yang berlangung secara terus menerus. Baik gerak tersebut terjadi secara lamban (evolusi), maupun berlangsung dalam skala yang cepat dan progresif (revolusi).

Dalam perspektif yang lebih luas, teori pembangunan, khususnya dalam lingkup ilmu sosial, terbagi dalam dua kategori. Yakni, teori pembangunan yang berparadigma pada modernisasi, dan pembangunan yang berparadigma pada ketergantungan. Teori berparadigma modernisasi adalah keseluruhan teori pembangunan yang bersifat makro. Memuat pembacaan laju perkembangan dan pertumbuhan ekonomi, dan perubahan sosial masyarakat. Selain bersifat makro, teori ini juga berhubungan dengan hal-hal mikro.Menyangkutnilai-nilaiindividuyang mampu mendorong proses transformasi sosio-kultur masyarakat (Jemadu, 2003: 223). Sedangkan teori pembangunan yang berparadigma ketergantungan mencakup keberadaan teori-teori pembangunan yang lebih dominan bersifat primitif, seperti 
halnya teori ketergantungan yang ada di banyak negara-negara terbelakang dan berkembang (Martin, 1995: 98).

Secara etimologis, pembangunan berasal dari kata bangun, yakni bentuk, cara menyusun atau susunan yang merupakan suatu wujud atau struktur. Sedangkan berdasarkan Kamus Besar Bahasa Indonesia, pembangunan adalah proses, cara, atau perbuatan membangun (KBBI., 2001: 81). Pembangunan sebagai sebuah proses mengandaikan pada pelaksanaan yang saling terkait, berkesinambungan, dan berkelanjutan. Adapun pembangunan sebagai 'cara' mensyaratkan pada serangkaian metode atau strategi yang sistematis, terstruktur untuk mencapai sasaran pembangunan. Dengan demikian, pembangunan dalam pengertian etimologi dapat dimaknai sebagai aktivitas 'membangun' yang dijalankan terus menerus melalui cara, strategi, pendekatan, atau metode tertentu yang terukur dan matang.

Adapun secara terminologis, Siagian (1994) sebagaimana dikutip oleh Ricky Wirawan dkk, (2015) pembangunan adalah suatu upaya atau serangkaian usaha pertumbuhan dan perubahan yang terencana dan dilakukan secara sadar oleh suatu bangsa, negara, dan pemerintah, menuju modernitas dalam rangka pembinaan bangsa (Wirawan dkk, 2015: 308). Pengertian pembangunan dalam perspektif demikian mensyaratkan pada tiga hal: pertumbuhan, perubahan, dan modernitas. Konsep pertumbuhan mengandaikan bahwa pembangunan harus menghadirkan peningkatan secara ekonomis, sehingga mendorong kemampuan suatu kelompok untuk terus berkembang, baik secara kualitatif maupun kuantitatif. Sedangkan konsep perubahan mensyaratkan mensyaratkan, bahwa pembangunan perlu menghadirkan perbaikan pada segala sektor kehidupan yang berorientasi pada perwujudan sistem dan struktur sosial kehidupan masyarakat yang modern.

Dalam kesempatan yang lain, Alexander (1994) sebagaimana dikutip oleh Tira Nur Fitria (2016) mendefinisikan pembangunan sebagai proses perubahan yang menyentuh keseluruhan sistem dan struktur sosial. Baik itu sistem politik, pendidikan, ekonomi, teknologi, infrastruktur, dan budaya (Fitria 2016: 30). Pengertian ini memiliki keserupaan dengan pembacaan Portes (1976), yang mengartikan pembangunan sebagai transformasi ekonomi, sosial dan budaya yang diperuntukkan untuk menghadirkan perbaikan pada setiap aspek kehidupan masyarakat. Deddy T. Tikson (2005) mendefinisikan pembangunan sebagai langkah transformasi ekonomi, sosial, dan budaya yang dilakukan secara sengaja dan terencana melalui pemberlakukan kebijakan dan strategi menunju kondisi yang dicita-citakan (Tikson, 2005: 135).

Meski secara teoritis memiliki berbagai pengertian, namun secara kontekstual, aktivitas pembangunan mempunyai tiga tema fundamental. Tiga tema fundamental dalam proses pembangunan adalah: Pertama, koordinasi, artinya sebuah pembangunan perlu mempertimbangkan aspek penyesuaian, penyeimbangan, dan pengaturan yang baik (Iwan dan Dahuri, 2004: 20). Pembangunan tidak boleh dijalankan sembarangan, pembangunan harus melalui proses perencanaan yang benar-benar matang, sehingga dalam pelaksanaannya dapat menghadirkan nilai-nilai positif bagi keberlanjutan hidup 
masyarakat tanpa terkecuali. Dalam tahap koordinasi ini, hal yang perlu dipertegas adalah sasaran, keikutsertaan, dan partisipasi masyarakat secara menyeluruh.

Kedua, alternatif yang lebih banyak dan terjadi secara sah. Artinya, bahwa agenda pembangunan harus menciptakan dan melahirkan dua atau beberapa kemungkinan kepada masyarakat, dimana kemungkinan tersebut memiliki orientasi untuk membantu dan mempermudah mereka dalam mendapatkan dan memperoleh layanan kehidupan yang tidak saja baik, namun juga terjangkau (Iwan dan Dahuri, 2004: 20). Poin ini lebih pada penguatan infrastruktur dan layanan kemasyarakatan. Ketiga, melahirkan aspirasi yang mengusung semangat humanis, bahwa pembangunan harus dapat mentransformasikan nilainilai kemanusiaan yang berorientasikan pada pemecahan masalah dan pembinaan nilai-nilai moral dan etika umat (Iwan dan Dahuri, 2004: 20). Pembangunan bukan semata tentang penguatan sektor ekonomis, peningkatan kualitas kesejahteraan hidup, dan pemberdayaan potensi alam. Lebih dari itu, pembangunan harus mampu mengantarkan masyarakat pada realitas hidup yang menjunjung tinggi nilai-nilai kemanusiaan, keadaban, dan moral.

\section{Pembangunan dan Paradigma Modernisasi: Tinjauan Teoritis}

Secara historis, sejarah kemunculan teori pembangunan tidak dapat dipisahkan dari peristiwa revolusi negara-negara Barat yang terjadi pada abad pertengahan. Revolusi Industri Inggris yang berlangsung pada abad ke17 menjadi titik awal munculnya ide-ide pembangunan dunia (Sztompka, 2007: 357). Keberhasilan Inggris membangun negaranya melalui kekuatan industri tekstil yang dikembangkan pada saat itu, akhirnya mendorong negara-negara lainnya melakukan langkah yang sama. Jadilah kemudian proyek pembangunan terjadi dalam skala besar-besaran, yang kemudian menandai lahirnya era modernisasi, dan melenyapnya segala warisan paradigma abad pertengahan dan era tradisional.

Dalam perkembangan berikutnya, modernisasi berkembang sebagai paradigma pembangunan yang digunakan oleh negara-negara Barat. Amerika Serikat, sebagai negara super power pada saat itu, menjadikan modernisasi sebagai satu-satunya agenda pembangunan yang dikampanyekan ke seluruh dunia. Puncaknya, pada kisaran 1940-an, khususnya pada tanggal 20 Januari 1949, yakni saat presiden Amerika Serikat Hary S Truman bersama Marshall Plan mengumumkan kebijaksanaan pemerintahnya. Menurut Truman seluruh dunia seharusnya mendapatkan "fair democratic deal" melalui intervensi Amerika Serikat untuk mengatasi masalah kemiskinan global (Sztompka, 2007: 357).

Agenda pembangunan global melalui paradigma modernisasi semakin menemukan momentumnya ketika beberapa tahun setelahnya muncul berbagai teori-teori pembangunan yang mengamini proyek modernisasi Barat. Salah satu teori pembangunan modern paling berpengaruh adalah teori pembangunan WW. Rostow.

\section{Teori Pembangunan WW. Rostow}

Dalam diskursus pembangunan era modern, teori pembangunan Rostow menjadi salah satu teori yang banyak dikenal di penjuru dunia. Teori 
pembangunan Rostow, meski secara spesifik lebih fokus pada pembangunan ekonomi, telah memberi banyak inspirasi bagi diskursus pembangunan dunia. Hal itu tidak lepas dari keberhasilan Rostow merumuskan bagaimana proses pembangunan dapat berjalan. Dari negara yang awalnya terbelakang (tradisional) kemudian bergeser menjadi negara modern.

Dalam teorinya, Rostow menjelaskan bahwa sebuah proses pembangunan akan mengalami lima tahap evolusi, yakni: 1) Masyarakat tradisional (the traditional society), 2) Prasyarat untuk tinggal landas (the preconditions for takeoff), 3) Tinggal landas (the take-off), 4) Menuju kekedewasaan (the drive to maturity), dan 5) Masa konsumsi tinggi (the age of high mass-consumption). Lima tahap ini menurut Rostow akan terjadi dalam proses yang multidimensional, meliput karakteristik perubahan keadaan ekonomi, sosial, dan politik di negara atau daerah yang bersangkutan (Prasetya 2016: 17).

\section{1) Masyarakat Tradisional (the} traditional society)

Dalam Kamus Besar Bahasa Indonesia, tradisional berarti cara sikap, berpikir, dan bertindaknya selalu berpegang teguh pada norma dan adat kebiasaan yang ada secara turun menurun; menurut tradisi (adat) (KBBI., 200: 622). Dengan demikian, masyarakat tradisional adalah masyarakat yang memiliki kecenderungan menjadikan nilai tradisi dan adat lokalnya sebagai pegangan hidup. Baik dalam bersikap, berpikir, bertindak, ataupun berperilaku.

Dalam pemikiran teori pembangunan Rostow, masyarakat tradisional adalah mereka yang kegiatan ekonominya memiliki cara dan metode terbelakang, baik dalam hal kegiatan produksi, distribusi, maupun konsumsi. Dalam pandangan Rostow, masyarakat yang memiliki karaktistik ini adalah masyarakat yang belum memiliki kemajuan dalam hal keilmuan dan teknologi, dan belum memiliki paradigma berpikir yang rasional. Sebaliknya, mereka lebih mengedepankan produkproduk tradisional, berupa adat ataupun tradisi yang diwariskan oleh para pendahulunya (Arsyad, 2004:47). Karena tata cara kehidupan yang terbelakang ini, masyarakat tradisional memiliki tingkat produktivitas bekerja yang rendah, sehingga tidak kompetitif untuk menghasilkan komoditas dalam skala besar. Sistem pencarian dan kehidupan mereka lebih banyak menggantungkan pada sektor pertanian, bukan industri.

\section{2) Tahap Prasyarat Tinggal Landas (the preconditions for take-off)}

Pada tahap ini, Rostow melihat masyarakat tengah berada dalam situasi transisi. Masyarakat mengupayakan dirinya seoptimal mungkin untuk menguatkan dan meningkatkan pertumbuhan ekonomi mereka. Dalam keyakinan Rostow, ketika masyarakat sudah dapat memaksimalkan pertumbuhan ekonomi, maka bersamaan dengan itu pertumbuhan dan perubahan pembangunan dengan sendirinya akan berjalan (Hendriyani, 2016: 21).

Rostow menekankan adanya keberanian, kesediaan, dan kesadaran masyarakat untuk melakukan perubahan. Perubahan yang dimaksud di sini adalah kemampuan diri untuk mensinergikan cara-cara tradisional, seperti kegiatan 
pertanian, dengan sistem kehidupan yang lebih modern. Menjadikan ilmu pengetahuan modern sebagai paradigma berpikir sehingga menjadi pintu gerbang masuknya temuan-temuan baru yang bisa membantu aktivitas perekonomian mereka. Dengan temuan baru tersebut, masyarakat akan menjadi tahu bagaimana menekan biaya produksi, memunculkan inovasi, sehingga secara signifikan akan dapat menggenjot dan mendorong aktivitas pertumbuhan dan pembangunan perekonomian secara efektif.

Ciri paling khas pada masyarakat ini adalah terintegrasinya aktivitas perekonomian tradisional dengan pemberlakuan sistem modern, seperti penggunaan teknologi. Selain itu, aktivitas perekonomian pada masyarakat ini juga ditopang oleh adanya kegiatan investasi dan kehadiran perbankan (Restiyanto, 2006: 176). Dengan demikian, kegiatan pembangunan pada tahap prasyarat tinggal landas, meski mengandaikan pada kehadiran ilmu pengetahuan dan teknologi, namun tidak kemudian meninggalkan sistem kehidupan tradisional. Sebaliknya, ada sinergitas yang membuat keduanya saling berpadu dan menguatkan.

\section{3) Tinggal Landas (the take-off)}

Ciri khas masyarakat yang ada pada tahap ini adalah tersisihnya sisitem kehidupan tradisional, diganti oleh sistem kehidupan masyarakat yang lebih modern. Kehidupan masyarakat lebih banyak ditopang oleh ilmu pengetahuan beserta segala produk dan temuannya, seperti halnya teknologi dan media massa (Pasaribu, 2001: 33). Realitas kehidupan mengalami pergeseran, di mana bangunan nilai-nilai lokalitas tidak lagi ada dalam sistem dan kebudayaan mereka. Masyarakat lebih cenderung menggunakan pola pikir rasional.

Pola pikir masyarakat yang kian rasional, serta penggunaan teknologi dan ilmu pengetahuan yang terjadi dalam skala lebih masif, dalam batasanbatasan tertentu, secara signifikan telah melahirkan pertumbuhan dan perubahan. Baik itu dalam hal sosial ekonomi, sosial politik, dan sosial budaya (Pasaribu, 2001: 33). Pada tahap ini, proses transformasi dan perubahan sosial terjadi dalam skala yang besar. Tercipta sebuah kemajuan dan inovasi teknologiyang begitu pesat. Sentrasentra ekonomi hadir di banyak tempat, pembangunan industri begitu menggeliat, sehingga secara radikal mengubah sistam dan pola hidup masyarakat.

Ciri khas yang paling dominan pada tahap ini adalah keberhasilan negara dalam menemukan sektor ekonomi unggulan (leading sector) (Pasaribu, 2001: 33). Sektor ekonomi unggulan secara signifikan akan membantu dan mendorong laju pertumbuhan, sehingga akan sangat membantu untuk mendongkrak sektor-sektor lainnya. Oleh karenanya, Rostow menakankan, bahwa setiap daerah ataupun masyarakat harus mampu memanfaatkan setiap kekayaan dan potensi alam yang ada di daerahnya. Selain itu, ketersediaan sumber daya manusia yang meliputi pendidikan dan penguasaan pada teknologi, merupakan prasyarat mutlak yang harus ada.

Berkaitan dengan konsep leading sector ini, Rostow menjelaskan bahwa setiap daerah memiliki aspek keunggulan ekonomi masing-masing. Dalam hal ini, Rostow melihat bagaimana Inggris (17831802) dapat menjalankan pembangunan tahap tinggal landas melalui sektor 
unggulan berupa tekstil. Prancis (1830 -1860) memiliki sektor jaringan jalan kereta api. Di Asia, Jepang (1878 -1900) dapat memasuki tahap tinggal landas dengan sektor ekonomi unggulan sutera. Di dataran Amerika Latin, Argentina (1935) dapat menjalan tahap pembangunan tinggal landas melalui sektor unggulan Industri substitusi impor (Pasaribu, 2001: 34). Persisnya, pembangunan tahap tinggal landas dalam perspektif Rostow mengandaikan pada terciptanya sistem sosio-kultur modern yang berbasis pada leading sector potensi ekonomi masingmasing negara.

\section{4) Menuju ke Kedewasaan (the drive to maturity)}

Pada aspek-aspek tertentu, proses pembangunan yang sudah menginjak pada tahap menuju kedewasaan, mempunyai kesamaan ciri dengan masyarakat tinggal landas. Kesamaan tersebut ada pada masifnya penggunaan teknologi sebagai instrumen aktivitas kehidupan mereka (Pasaribu, 2001: 34). Namun demikian, terdapat aspek pembeda antara masyarakat yang menuju kedewasaan dan mereka yang ada di era tinggal landas. Yaitu cara pandang mereka dalam memperlakukan sektor unggulan tersebut.

Sebagaimana telah disinggung di atas, bahwa sektor ekonomi unggulan pada masyarakat tinggal landas senantiasa mengandalkan sektor unggulan berdasarkan produk unggulan sumber daya alam masing-masing negara. Sehingga cara-cara seperti ini bisa dibilang memiliki ketergantungan cukup besar pada ketersediaan sumber daya alam. Hal demikian kontras dengan pembangunan yang sudah ada di level menuju dewasa. Masyarakat yang ada di era ini sudah dapat berpikir lebih maju dan modern, menghasilkan produk unggulan (leading sector) berdasarkan daya kreatif mereka untuk tidak sekadar memeproduksi, namun juga mereproduksi komoditas baru. Apa yang disebut oleh mereka sebagai leading sectore tidak lagi ditentukan oleh keberadaan potensi kekayaan alam di negera tersebut, melainkan lebih pada keberhasilan mereka dalam mengolah, membudidayakan, memanfaatkan, dan mengkreasikan berbagai sumber daya alam. Menjadikannya sebagai produk baru yang menghasilkan daya ekonomis (Pasaribu, 2001: 34).

Dalam kaitan ini, Rostow memberi contoh bagaimana keberhasilan Inggris mendudukkan dirinya sebagai negara nomor satu dunia dalam hal industri besi dan peralatan teknik berat. Padahal pada tahun-tahun sebelumnya, sektor ekonomi unggulan mereka bergerak di bidang Tekstil. Di Asia, Jepang yang pada tahap pembangunan tinggal landas berhasil merubah leading sector mereka, yang awalnya bergerak di bidang industri sutera semakin mengalami peningkatan. Kemudian merambah pesat pada sektor industri otomotif dan teknologi secara umum.

\section{5) Masa Konsumsi Tinggi (The Age of High Mass Consumption)}

Tahap konsumsi tinggi merupakan pemikiran terakhir Rostow tentang tahap pembangunan masyarakat. Pada level ini, pembangunan masyarakat tidak lagi bergerak di bidang produksi ataupun distribusi. Siklus pembangunan negara yang awalnya bergerak di bidang produksi melalui kegiatan industri ataupun pertanian kini 
mengalami pergesaran. Berganti pada tahap perkembangan masyarakat yang didominasi oleh perilaku konsumsi yang tinggi (Pasaribu, 2001: 35).

Berkaitan dengan sikap konsumtif ini, Rostow menjelaskan salah satu ciri kehidupan di level ini adalah adanya pandangan kritis yang berdatangan dari banyak pihak. Dalam perspektif sosiologis, kehadiran masa konsumsi tinggi kemudian dikenal sebagai sebuah fenomena baru berupa kebudayaan populer (Pop Culture), yang sekaligus mengawali lahirnya era postmodernitas. Jean Baudrillard (19292007)menyebutera memuncaknya aktivitas konsumsi ini sebagai era hiperealitas. Yakni sebuah era dimana perilaku konsumsi masyarakat tidak lagi dibentuk oleh nilai, melainkan oleh simbol dan status (Hidayat, 2012: 56). Bukan lagi berdasarkan pada aspek kebutuhan (needs), melainkan lebih kepada gaya hidup yang berpijak pada hasrat dan keinginan (desire).

Pada batasan ini, problem pembangunan modernisai bukan semata adapadatidakterkontrolnyapolakonsumsi masyarakat, namun juga berkaitan dengan berbagai krisis sosial yang berkaitan dengan ketidakdilan, ketimpangan, kemiskinan, dan semacamnya. Pembangunan dunia menghadapi krisis di berbagai lini, sehingga mengilhami para ilmuan sosial, khususnya para pakar pembangunan, melontarkan kritik dan memunculkan gagasan-gagasan baru. Pembangunan modern dianggap gagal dalam mendatangkan kesejahteraan, sehingga membutuhkan pendekatan baru. Salah satunya adalah dengan model pembangunan milenium, atau yang populer dengan sebutan Millennium Development Goals (MDGs).

\section{Pembangunan Era Millenium (MDGs)}

Secara historis, kelahiran pembangunan era Milenium, Millennium Development Goals (MDGs), tidak dapat dikecualikan dari Konferensi Tingkat Tinggi (KTT) Milenium atau Millenium Summit yang berlangsung di Markas Besar Perserikatan Bangsa-Bangsa di Newyork, 6-8 September 2000 silam. Pada kesempatan itu, para pemimpim dunia, khususnya negara-negara yang tergabung dalam organisasi Perserikatan Bangsa-Bangsa (PBB) secara serentak sepakat untuk merumuskan sebuah model pembangunan baru dalam rangka menjawab dan menyelesaikan sekian persoalan global. Kesepakatan mereka tersebut kemudian terwujud dalam deklarasi Milenium PBB, yang saat itu diikuti oleh 189 negara anggota, termasuk Indonesia (Syafrawati, 2006: 17)

Dalam kaitan ini, negara-negara yang terlibat sebagai deklarator bersedia untuk menjalankan kemitraan global baru guna mengurangi kemiskinan yang pada saat itu menjadi momok menakutkan negara-negara dunia, khususnya negara berstatus berkembang. Deklarasi milenium ini pada akhirnya dikenal sebagai proyek pembangunan milenium, atau yang kemudian populer dengan sebutan Millennium Development Goals (MDGs) yang akan berlangsung dalam masa 2000-2015 (Sulistyo, dkk, 2010: 18).

Sebagai sebuah proyek pembangunan, MDGs memiliki delapan butir sasaran, yaitu; 1) mengakhiri kemiskinan dan kelaparan, 2) pendidikan universal, 3) kesetaraan gender, 4) kesehatan anak, 5) kesehatan ibu, 6) penanggulangan HIV/ AIDS, 7) keberlanjtan lingkungan, dan 8) kemitraan global (Utomo, 2007: 233). Kedelapan butir pembangunan MDGs 
tersebutkemudianmenjadicetak biruyang disetujui oleh keseluruhan negara-negara dunia, dan oleh semua lembaga-lembaga dunia yang memiliki peran dan fungsi pembangunan dunia. Untuk mendukung delapan program MDGs tersebut, negaranegara berkembang, seperti halnya Indonesia, memiliki tanggungjawab sebagai negera yang bergerak di tingkat bawah. Sedangkan negaranegara maju, seperti halnya Amerika Serikat, berkewajiban mendukung dan memberikan bantuan terhadap upaya keberhasilan setiap tujuan dan target MDGs (Wahyuningsih, 2017: 393).

Di Indonesia sendiri, sebagai salah satu negara yang turut menandatangani deklarasi pembangunan milenium, program MDGs memberi peluang dan harapan cukup besar dalam upaya mengatasi berbagai persoalan dan krisis sosial. Apalagi dengan status Indonesia sebagai negara berkembang, instrumen pembangunan global MDGs diharapkan memberi pengaruh signifikan untuk turut membantu mengatasi sekian persoalan sosial yang pada saat itu belum dapat sepenuhnya terentaskan dengan baik. Mendorong laju pertumbuhan dan pemerataan ekonomi, dengan tujuan memangkas ketimpangan sosial. Lebihlebih, negara-negara yang statusnya masih berkembang seperti Indonesia memiliki problem krusial dengan pemerataan.

Namun demikian, di tengah berbagai problem internal yang melanda Indonesia, seperti maraknya aksi teror, menggeliatnya konflik antar komunitas, dan belum stabilnya politik dalam negeri pascareformasi 1998, secara langsung membuat pelaksanaan pembangunan MDGs menemui masalah (Sulistyo,dkk, 2010: 18). Beberapa sasaran program strategis seperti kemiskinan, kesehatan, ketimpangan sosial dan penanganan HIV-AIDS terancam tidak tercapai. Akibatnya, menjelang lima tahun puncak penyelanggaraan pembangunan MDGs, tepatnya pada tahun 2010, Indonesia terancam menemui kegagalan dalam menjalankan tiga butir utama sasaran program MDGs. Bahkan, dalam laporan rutin pencapaian MDGs di kawasan Asia Pasifik yang berjudul, Achieving the Millennium Development Goals In an Era of Global Uncertainity: Asia-Pasific Regional Report 2009/10, PBB menempatkan Indonesia sebagai negara paling rentan. Indeks kerentanan Indonesia dalam pembangunan MDGs berada di posisi menengah bersama Filipina, Nepal, dan Papua Nugini, serta lebih buruk dibandingkan posisi Vietnam, Bangladesh, dan India. Bahkan, Indonesia pada saat itu kalah jauh dengan negara-negara tetangga, Malaysia, misalnya, berhasil melakukan menjalankan program MDGs sejak tahun 2003 (Sulistyo, dkk, 2010: 18).

Dengan demikian, secara umum program pembangunan MDGs Indonesia yang dijalankan dalam rentan waktu 2000-2015 menemui banyak kegagalan. Faktor kurangnya kerjasama pemerintah pusat dengan pemerintah daerah serta kurangnya keterlibatan pihak swasta maupun masyarakat di dalam negeri (Lisbet, 2013: 151), adalah sekian problem yang menghambat pembangunan MDGs di Indonesia. Di samping itu, problem yang tak kalah krusialnya adalah keterbatasan dana dalam negeri, serta instabilitas politik nasional. Sekian problem tersebut mau tidak mau, sedikit banyak turut mempengaruhi jalannya pembangunan MDGs di Indonesia (Sulistyo,dkk, 2010: 19). 


\section{Pembangunan Berkelanjutan (SDGs)}

Berlangsungnya Sidang Umum Perserikatan Bangsa-Bangsa (PBB) ke70 pada bulan September 2015 di New York, Amerika Serikat, menjadi lembaran sejarah baru dalam proses pembangunan dunia. Dalam sidang ini, hadir 193 kepala negara dan pemerintahan dunia untuk menyepakati agenda pembangunan baru yang tertuang dalam dokumen berjudul Transforming Our World: The 2030 Agenda for Sustainable Development (Utomo, 2007: 233). Agenda pembangunan tersebut kemudian menghasilkan sebuah persetujuan, yang kemudian dinamakan sebagai Sustainable Development Goals (SDGs).

Sejak diresmikan pada tahun 2015 di Rio De Janeiro, Brasil, pembangunan berbasis SDGs secara umum memiliki visimisi melanjutkan dan mengembangkan sekian program pembangunan sebelumnya, yakni era pembangunan abad milenium, Millenium Development Goals (MDGs) (Ishartono dan Santoso tri raharjo, 2016: 159). Namun demikian, sekalipun SDGs mengemban visi melanjutkan pembangunan MDGs, bukan kemudian sasaran program kerja keduanya memiliki keserupaan secara total.

Pola kerja MDGs menempatkan negara-negara maju sebagai pengontrol, di saat bersamaan negara-negara berkembang seperti Indonesia, lebih didudukkan sebagai pihak yang 'pekerja'. Dengan artian, MDGs memberikan tanggungjawab yang tidak berimbang antara negara maju dan negara berkembang. Selain itu, masih terdapat sekian sisi kelemahan dalam pola kerja MDGs, khususnya dalam hal perancangan dan eksekusinya yang eksklusif dan sangat birokratis (Panuluh dan Meila Riskia Fitri, 2016: 4). MDGs menerapkan pembangunan bersifat positivistik, kaku, dan normatif tanpa mengikutsertakan peran non-pemerintah. Kenyataan ini menyebabkan proyek MDGs kerapkali abai nilai-nilai emansipatifdan partisipatif, karena dalam prosesnya kerapkali abai pada suara yang muncul dari luar mereka (Panuluh dan Meila Riskia Fitri, 2016: 4).

Kenyataan di atas jauh berbeda dengan pola kerja SDGs. Cara kerja SDGs sendiri lebih mengakomodasi masalah-masalah pembangunan secara lebih komprehensif, baik kualitatif maupun kuantitatif. Selain itu, SDGs menempatkan negara-negara peserta dalam satu kesempatan dan kedudukan yang sama, sejajar, dan seimbang. Negara-negara maju yang dalam MDGs berfungsi sebagai negara pengontrol, kini dalam SDGs memperoleh tanggungjawab dan peran kerja yang sama. Dengan demikian, struktur hierarki yang ada pada MDGs tidak akan lagi ditemukan pada sistem SDGs (Panuluh dan Meila Riskia Fitri, 2016: 5). SDGs mempunyai sifat universal, memberikan peran yang seimbang kepada seluruh negara dan organisasi pembangunan dunia untuk berkontribusi penuh terhadap pembangunan dalam upaya menciptakan tatanan masyarakat dunia yang sejahtera dan berkeadilan. Sederhananya, hal mendasar yang menjadi pembeda SDGs dengan pembangunan MDGs sebelumnya adalah sifat pembangunan SDGs yang mengedepankan pola partisipatif antara negara maju, negara berkembang, organisasi non-pemerintah, dan elemen-elemen masyarakat secara keseluruhan.

Sebagai wujud kelanjutan era MDGs, agenda pembangunan berkelanjuatan (SDGs) mengusung spirit perubahan 
dalam upaya menciptakan tatanan kehidupan yang lebih baik. Yakni terciptanya realitas kehidupan global yang tidak saja lebih maju, berkembang, dan transformatif. Lebih dari itu, SDGs mengemban semangat besar untuk menciptakan iklim kehidupan masyarakat dunia yang mengarah pada terjaminnya hak asasi manusia, serta kesetaraan dalam rangka mendorong pembangunan sosial, ekonomi dan lingkungan hidup yang kesemuanya bermuara pada tercapainya kesejahteraan hidup (Erwandari, 2017: 23-25).

Dalam upaya mewujudkan perubahan tersebut, model pembangunan berkelanjutan (SDGs) memperlakukan prinsip-prinsip pembangunan universal, integratif, dan inklusif untuk memastikan bahwa setiap individu, kelompok, atau golongan ikut berpartisipasi dan menikmati pembangunan secara menyeluruh. Sebab itu, masalah-masalah sosial yang bersentuhan langsung dengan kemiskinan, kesenjangan, dan perubahan iklim sebagai efek dari ketidakadilan, ketidaksetaraan dan ketidakseimbangan adalah wilayah-wilayah fundamental. Dikatakan fundamental karena sebuah pembangunan pada dasarnya harus mengemban visi universalitas, mengedepankan partisipasi lapisan masayarakat tanpa terkecuali (Ishartono dan Santoso Tri Raharjo, 2016: 164).

Berkaitan dengan tujuan pembangunan di atas, SDGs memiliki program kerja pokok yang kemudian dirumuskandalamlimaprinsipdasaryang bertujuan untuk menyeimbangkan dua aspek pembangunan, yakni aspek sosial dan aspek lingkungan (Sari, 2016: 180). Kelima prinsip dasar tersebut adalah: 1) manusia (people). Prinsip ini mensyaratkan pada terwujudnya pembangunan global yang memuat spirit kemanusiaan. Pembangunan SDGs mencitakan realitas pembangunan yang menjunjung tinggi nilai-nilai kemanusiaan, emansipatif, keadaban, dan penghormatan terhadap segala hak; 2) bumi (planet), dalam upaya menciptakan pembangunan dunia yang berkelanjutan, maka SDGs tidak saja menekankan pada aspek pertumbuhan ekonomis. Namun lebih dari itu, juga mengusung visi menjaga keberlangsungan lingkungan, menjaga ekosistem, dan menjaga perubahan iklim secara baik dan berkelanjutan; 3) kemakmuran (prosperity), prinsip menekankan pada perbaikan taraf kehidupan masyarakat dunia secara menyeluruh, khususnya negara-negara berkembang yang memiliki problem kelaparan, kemiskinan, dan ketimpangan; 4) perdamaian (peace), bahwa SDGs memiliki kepentingan untuk turut serta dalam upaya menciptakan kedamaian dan romantisme dunia. Dalam hal ini, negara-negara yang terlibat dalam penandatanganan SDGs harus berperan aktif mendukung perwujudan tatanan global yang aman, damai, dan harmonis; dan 5) kerjasama (partnership). Penguatan hubungan antarnegara-nagara dunia sebagai langkah membangun kemitraan global yang saling bersinergi. Lima prinsip dasar ini diringkas dengan sebutan 5P yang menaungi sekeluruhan program pembangunan SDGs. Kelima prinsip di atas memiliki keterkaitan satu sama lain, sehingga dalam tahap pelaksanaannya tidak dapat dipisahkan. Saling berhubungan dan terintergasi dalam satu struktur pembangunan yang utuh dan integral (Panuluh dan Meila Riskia Fitri, 2016: 6). 
Dalam upaya mensukseskan program pembangunan SDGs, lima prinsip dasar di atas kemudian diterjemahkan dalam butiran sasaran kerja. Terdapat 17 Tujuan dan 169 Sasaran kerja SDGs. Jika dibandingkan dari sasaran MDGs, jumlah tujuan kerja SDGs jauh lebih banyak daripada MDGs yang hanya berjumlah tujuh. Keseluruhan tujuan program kerja SDGs tersebut adalah: 1) tanpa kemiskinan, 2) tanpa kelaparan, 3) kesehatan yang baik dan kesejahteraan, 4) pendidikan berkualitas, 5) kesetaraan gender, 6) air bersih dan sanitasi, 7) energi bersih dan terjangkau, 8) pertumbuhan ekonomi dan pekerjaan yang layak, 9) industri inovasi dan infrastruktur, 10) mengurangi kesenjangan, 11) keberlanjutan kota dan komunitas, 12) konsumsi dan produksi bertanggungjawab, 13) aksi terhadap iklim, 14) kehidupan bawah laut, 15) kehidupan di darat, 16) institusi peradilan yang kuat dan kedamaian, 17) kemitraan untuk mencapai tujuan (Pribadi, 2015: 927).

Dalam konteks pembangunan Indonesia, komitmen pemerintah Indonesia terhadap agenda pembangunan SDGs tergambar jelas dalam Peraturan Presiden No 59 tahun 2017 tentang Pelaksanaan Pencapaian Tujuan Pembangunan Berkelanjutan, tanggal 4 Juli 2017 (Hayati dan Muhammad Arif, 2016: 131). Melalui Perpres tersebut, pemerintah kemudian melakukan penyesuaian rancangan SDGs dengan Rencana Pembangunan Jangka Panjang Nasional, Tahun 2005-2025 dan Rencana Pembangunan Jangka Menengah Nasional, Tahun 2015-2019. Penyelarasan tersebut kemudian diterjemahkan dalam rancangan kebijakan yang lebih terfokus lagi, berupa Aksi Rencana Nasional (ARN) dan Aksi Rencana Daerah (ARD) (Media Indonesia, 27/09/17).
Aksi Rencana Nasional merupakan dokumen yang memuat program dan kegiatan rencana kerja 5 (lima) tahunan untuk pelaksanaan berbagai kegiatan yang secara langsung dan tidak langsung mendukung pencapaian SDGs yang sesuai dengan sasaran nasional. Sedangkan Rencana Aksi Daerah SDGs yang selanjutnya disingkat RAD SDGs adalah dokumen rencana kerja 5 (lima) tahunan di tingkat provinsi untuk melaksanakan berbagai kegiatan yang secara langsung dan tidak langsung mendukung pencapaian SDGs yang sesuai dengan sasaran pembangunan daerah. Sasaran pembangunan nasionaldaerah yang dimaksud meliputi: menjaga peningkatan kesejahteraan ekonomi masyarakat secara berkesinambungan, menjaga keberlanjutan kehidupan sosial masyarakat, dan menjaga kualitas lingkungan hidup serta pembangunan yang inklusif dan terlaksananya tata kelola yang mampu menjaga peningkatan kualitas kehidupan dari satu generasi ke generasi berikutnya.

Untuk mencapai sasaran di atas, SDGs Indonesia menerapkan pola pembangunan dengan prinsip No One Will Be Left Behind, yang artinya pelaksanaan pembangunan harus memberi manfaat untuk semua (Fitri, 2016: 9). Pembangunan tidak boleh terpusat pada satu daerah atau satu kawasan, namun harus menyebar luas dan menyasar setiap daerah. Baik dari tingkat provinsi, kota, kabupaten, kecamatan, sampai struktur yang terkecil sekalipun, yaitu pedesaan. Untuk mewujudkan ini semua, perlu adanya transparansi proses sinkronisasi pembangunan. Bahwa pembangunan tidak boleh bersandar pada peran dan fungsi tunggal pemerintah, namun juga harus melibatkan semua pihak secara 
kolektif. Seperti halnya ormas, filantropi, pelaku usaha, akademisi, dan pemangku kepentingan lainnya. Semua pihak tersebut secara aktif ikut dilibatkan. Baik dalam hal perencanaan, pelaksanaan, dan pemantauan serta evaluasi pembangunan SDGs ke depan. Semua ini dijalankan dalam rangka menanamkan prinsip pemerataan.

\section{Kearifan Lokal: Sebuah Tinjauan Konseptual}

Dalam diskursus keilmuan sosial, term 'nilai kearifan lokal' sesungguhnya bukan barang baru. Dalam banyak kesempatan, khususnya yang berhubungan dengan isu pembangunan dan lokalitas, term 'nilai kearifan lokal' seringkali muncul, atau bahkan dimunculkan di ruangruang publik. Entah itu didudukkan sebagai tema kebudayaan, sosiologis, politik, pendidikan, ataupun ekonomi. Konsep ini semakin populer setelah banyak negara menjadikannya sebagai strategi pengenalan dan pemasaran pengembangan-pembangunan daerah.

Jika ditilik lebih dalam, secara etimologi term 'nilai kearifan lokal' merupakan wujud kesatuan dari tiga kata dasar: nilai, kearifan, dan lokal. Menurut kamu besar bahasa Indonesia, nilai identik dengan sifat-sifat atau hal-hal yang penting, bermanfaat, dan berguna bagi kemanusiaan (Departemen Pendidikan dan Kebudayaan, 1999: 615). Adapun kata 'kearifan' berasal dari kata dasar arif, yang artinya bijaksana; cerdik pandai berilmu (Departemen Pendidikan dan Kebudayaan, 1990:48). Lokal dalam pengertian Kamus Bahasa Indonesia berarti setempat; terjadi (berlaku, ada, dsb) di satu tempat saja, tidak merata (Departemen Pendidikan dan
Kebudayaan, 1990:530). Dengan demikian, nilai kearifan lokal adalah seperangkat nilai, kreativitas, atau pandangan yang memuat unsur kebijaksanaan, berkeadaban dan berperadaban yang berlangsung, berada, atau berlaku di satu tempat atau lokasi tertentu.

Adapun dalam pengertian terminologi, nilai kearifan lokal mengacu pada berbagai kekayaan budaya yang tumbuh dan berkembang dalam sebuah masyarakat yang dikenal, dipercayai dan diakui sebagai elemen-elemen penting yang mampu mempertebal kohesi sosial di antara warga masyrakat (Abdullah, 2008: 7). Pengertian ini mengisyaratkan bahwa nilai kearifan lokal hakikatnya muncul dan tumbuh dari kemampuan dan kreativitas masyarakat, yang kemudian terinternalisasi dalam kesadaran, pikiran, sikap, dan perilaku keseharian mereka. Konsep kohesi sosial dalam pembacaan ini mensyaratkan pada fungsi dan peran strategis kearifan lokal sebagai pembentuk integritas dan kesatuan masyarakat.

Menurut Mitchell, et al. (2000) dikutip oleh Aulia dan Arya Hadi Dharmawan (2014), term kearifan lokal berasal dari sistem pengetahuan dan pemberdayaan nilai-nilai lokal, tradisi, dan adat (Aulia dan Arya Hadi Dharmawan, 2014:346). Adapun menurut Zakaria (1994) sebagaimana dikutip Arafah (2002), konsep kearifan lokal bisa dipahami sebagai pengetahuan kebudayaan yang ada dalam sistem dan struktur sosial masyarakat tertentu yang di dalamnya memuat serangkaian pengetahuan kebudayaan yang terdiri dari sejumlah pengetahuan kebudayaan, serta tata cara pengelolaan, pemberdayaan, dan pemanfaatan sumber daya alam-sosial secara lestari (Arafah, 2002: 231). Kearifan tersebut berisikan gambaran tentang 
anggapan masyarakat yang bersangkutan tentang hal-hal yang berkaitan dengan struktur lingkungan, fungsi lingkungan, reaksi alam terhadap tindakan-tindakan manusia, dan hubungan-hubungan yang sebaiknya tercipta antara manusia (masyarakat) dan lingkungan alamnya (Aulia dan Arya Hadi Dharmawan, 2014: 346).

Dalam kesempatan yang lain, nilai kearifan lokal juga didefinisikan sebagai pengetahuan, gagasan, nilai, keterampilan, pengalaman, tingkah laku, dan kebiasaan adat yang dilakukan oleh masyarakat di wilayah tertentu (Hayati, 2016, 40). Dengan demikian, kearifan lokal sebagai bagian dari realitas masyarakat yang memiliki kompleksitas nilai, dalam batasan-batasan tertntu, memiliki fungsi sebagai strategi dan pandangan hidup untuk menjawab berbagai masalah dalam upaya pemenuhan kebutuhan masyarakat lokal terkait. Berkaitan dengan fungsi nilai kearifan lokal lokal di atas, Sirtha (2003) sebagaimana dikutip oleh Sartini (2004), menyebutkan bahwa kearifan lokal yang terdiri dari kebudayaan, trdisi, pengetahuan, kreasi, dan seperangkat nilai-nilai lokal lainnya memiliki fungsi sebagai: 1) konservasi dan pelestarian sumberdaya alam; 2) mengembangkan sumber daya manusia; 3) pengembangan kebudayaan dan ilmu pengetahuan; 4) petuah, kepercayaan, sastra dan pantangan (Sartini, 2004: 127). Dalam kaitan inilah, maka fungsi-fungsi kearifan lokal di atas, khususnya fungsi pengembangan kebudayaan dan sumber daya alam, sesunguhnya dapat dimanfaatkan sebagai instrumen pembangunan kita, Indonesia. Kearifan lokal dapat menjadi jawaban dari sekian strategi pembangunan yang selama ini belum menunjukkan perkembangan, perubahan, dan kemajuan maksimal. Khususnya pembangunan di level daerah yang keberadaannya masih memegang teguh nilai dan norma lokalitas, seperti halnya keseluruhan daerah yang ada di Kepulauan Madura.

\section{Deskripsi Nilai Kearifan Lokal Masyarakat Madura}

Diskursus mengenai nilai kearifan lokal Madura secara tidak langsung mengantarkan kita pada realitas sosial masyarakat Madura dari banyak aspek, karena seperti pengertian dasarnya, bahwa kearifan lokal merujuk pada setiap pengetahuan, gagasan, nilai, keterampilan, pengalaman, tingkah laku, dan kebiasaan adat yang dilakukan oleh masyarakat di wilayah tertentu (Hayati, 2016, 40). Dengan demikian, nilai kearifan lokal dalam sub bahasan ini tidak melulu tentang wujud kebudayaan Madura an sich. Melainkan lebih luas dari itu, berkaitan erat dengan sistem dan struktur sosial masyarakat Madura secara menyeluruh.

Kebudayaan sebagai salah satu wujud nyata nilai kearifan lokal adalah mencakup pada aspek yang sangat luas. Kebudayaan bukan semata tentang wujud kreativitas, seni, karya, tradisi, ataupun adat. Lebih dari itu, kebudayaan juga mencakup tentang paradigma berpikir, ilmu pengetahuan, sistem sosial, dan tata kehidupan masyarakat. Karenanya, ketika kita membicarakan kebudayaan Madura, maka secara langsung akan mengantarkan kita pada pembahasan tentang sisi kehidupan masayarakat Madura secara menyeluruh dan luas. Persisnya, antara nilai kearifan lokal dan kebudayaan adalah satu kesatuan yang tidak dapat dipisahkan. Keduanya merupakan bangunan realitas sosial 
yang saling berkaitan, bahkan ada dalam ruang sosial yang sama.

Dari keseluruhan tema kearifan lokal masyarakat Madura, terdapat tema-tema pokok yang sejauh ini dikenal lengket oleh masyarakat umum dengan realitas kebudayaan masyarakat Madura. Beberapa tema pokok tersebut diantaranya: religiusitas, pesantren, kerapan sapi, sate, remoh, sandur, tanian lanjheng, tari pecut, sape sono. Keseluruhan wujud kebudayaan ini seolah telah mengidentitas dalam kebudayaan Madura. Bahkan, tanpa menyebutkan dari mana kebudayaan tersebut berasal, mayoritas dari kita akan akan tahu, dan pikiran kita secara lagsung akan tertuju pada Madura. Hanya saja, seiring derasnya arus globalisasi yang merangsek masuk ke berbagai sisi kehidupan masyarakat Madura, tema-tema pokok tersebut pelan-pelan mengalami kemunduran dan pengikisan.

Dalam hal arsitektur, nilai kearifan lokal masyarakat Madura dapat kita temukan pada ciri atau khas konstruksi tempattinggalmereka, sepertihalnyaroma bangsal, roma pegun dan roma pacenan. Tiga arsitektur rumah ini umumnya kita dapati di wilayah-wilayah pedesaan. Masingmasing memiliki makna tersendiri yang merepresentasikan kelas sosial penghuni atau pemiliknya. Dalam tradisi lama, tipe roma bangsal biasanya dimiliki oleh kalangan priyayi Madura, seperti klebun (sebutan kepada kepala desa]. Sementara, tipe roma pegun mencerminkan bahwa warga yang menempatinya berasal adalah kalangan ekonomi menengah. Sedangkan arsitektur rumah yang berupa roma pacenan adalah rumah kalangan masyarakat umum yang secara kelas sosial ada pada tingkat bawah (Susanto,
2007: 97). Dengan melihat model arsitektur dan struktur ornamental rumah orang-orang Madura tersebut, tampak jelas bahwa wujud hierarki sosial mereka tidak saja dibentuk melalui simbol-simbol kekuasaan sebagaimana yang terjadi pada masyarakat umum lainnya. Lebih menarik dari itu, pun juga dibentuk oleh perbedaan bentuk atau tipe bangunan rumah yang mereka tempati.

Selain dari aspek arsitektur rumah, nilai kearifan lokal masyarakat Madura juga bisa kita dapati dalam seni ketatabahasaan atau kesusatraan Madura. Ada banyak adagium dan kata bijak bahasa Madura yang memuat pesan akan pentingnya moral, jati diri, budi luhur, sifat terpuji, dan kebaikan lainnya. Tipologi masyarakat Madura yang kental dengan nilai-nilai penghormatan dan etika, secara signifikan telah berpengaruh besar terhadap wajah kesusatraan atau ketatabahasaan masyarakat setempat. Dalam kaitan ini, dapat kita katakan bahwa sebagian nilai kearifan lokal Madura, selain direpresentasikan melalui seni, dan arsitektur perumahan, juga direpresentasikan melalui tata kebahasaan dan kesusatraan masyarakat setempat. Misalnya, peribahasa yang berbunyi saporana bisaos, coma terro ngormadhâ ajunan bâdhâna sanaos namong jhuko' bujâ cabbhi. Secara tekstual kalimat ini memiliki arti, mohon maaf sebesar-besarnya, maksud hati ingin memberi penghormatan yang lebih, tapi adanya hanya cabe dan garam saja (Abdullah, 2008: 7). Dalam kanyataannya, hidangan yang mereka suguhkan lengkap, bahkan cukup mewah. Ada daging, ikan, nasi, telur dan lainnya. Secara semiotik, ungkapan di atas menggambarkan betapa besarnya keinginan mereka untuk menghormati tamu, dan juga sikap kerendahan hati mereka pada lingkungan. 
Penghormatan adalah salah satu nilai kearifan lokal yang mengidentitas dalam sistem dan struktur sosial masyarakat Madura. Besarnya sikap penghormatan tersebut dalam dapat kita identifikasi dari uangkapan, Bhuppa'- Bhâbhu'- Ghuru - Rato (Ayah, Ibu, Guru, dan Pemimpin pemerintahan). Kepada figur-figur utama itulah kepatuhan hierarkis orangorang Madura menampakkan wujudnya dalam praksis kehidupan sosial mereka (Susanto, 2007: 97). Kapatuhan di sini, khususnya pada Ayah, Ibu, dan Guru bagi masyarakat Madura adalah standar moral tinggi yang menjelaskan posisi kpribadian dan perilaku etik seorang. Mereka yang tidak patuh terhadap orang tua dan guru akan dianggap sebagai pribadi yang tidak berakhlak, sehingga akan mendatangkan pandangan jelek dan buruk dari sekitar. Melawan, membangkang, atau berbuat tidak sopan pada guru dan orang tua adalah perbuatan sangat tercela.

Kepada seorang guru, masyarakat Madura mempunyai pengakuan dan penghormatan yang sangat besar. Terutama pada guru-guru agama yang telah membimbing dan mengajari mereka masalah keagamaan (Taufiqurrahman, 2007: 3). Guru agama dalam pengakuan masyarakat Madura bisa berupa ustadz/ ustadzah, kiai langgar, kiai pesantren. Itulah sebabnya, dalam banyak kesempatan, sikap dan perilaku hormat masyarakat Madura kepada seorang Kiai (sebagai salah satu guru agama) sangat tingggi dan penuh totalitas. Karena dalam pandangan mereka, Kiai bukan saja tentang agama, namun juga referensi utama dalam setiap aspek kehidupan.

Berkenaan dengan guru agama ini, di kalangan masyarakat Madura terkenal istilah ghuru tolang. Istilah ini mereka tujukan kepada seorang guru agama yang telah berjasa besar mengajari mereka agama, khususnya baca Al-Qur'an (ngaji) semenjak masih kecil. Boleh di bilang, ghuru tolang dalam sistem tradisi dan kebudayaan masyarakat Madura adalah guru di atasnya guru. Karena dalam pandangan mereka, ghuru tolang adalah sosok pribadi penyabar nan sahaja yang sangat berjasa dalam hal keagamaan. Guru agama yang pertama kali memperkenalkan mereka tentang bacaanbacaan Al-Qur'an dan aktivitas sholat. Dalam tradisi keagamaan masyarakat Madura, kemampuan membaca AlQur'an dan menjalankan ibadah shalat adalah standar paling sederhana untuk menggolongkan kecakapan dan kedalaman sisi keagamaan seseorang.

Nilai kearifan lokal lain yang mengidentitas dalam sistem kebudayaan masyarakatMaduraadalahaspeksolidaritas (Shodiq, 2017: 115.). Solidaritas orang Madura sebagai masyarakat kepulauan tidak dapat dipungkiri keberadaannya. Sifat ini sangat kental dalam kehidupan dan keseharian mereka. Solidaritas menjadi sebuah sistem sosial yang khas dengan masyarakat Madura. Dalam kaitan ini, kegiatan-kegiatan kemasyarakatan, seperti remoh, misalnya, adalah wujud kebudayaan yang merepresentasikan ikatan solidaritas masyarakat Madura. Dalam uangkapan sehari-hari, masyarakat Madura sering menyebut orang sekitarnya sebagai taretan thibi', yang memiliki arti saudara sendiri, meski pada nyatanya di antara mereka tidak ada hubungan kekeluargaan.

Dengan demikian, jika kita sederhanakan, keseluruhan nilai-nilai kearifan lokal masyarakat Madura sesungguhnya bermuara pada tiga hal, yakni religiusitas, solidaritas, dan moral. 
Religiusitas adalah sekian konstruksi nilai-nilai lokal yang mengandaikan pada penghormatan, pengagungan, pengakuan, dan pemuliaan pada nilai dan simbol-simbol keagamaan (Islam). Sedangkan solidaritas merujuk pada serangkaian nilai yang mengandaikan pada kuatnya hubungan, integrasi, dan kohesi sosial mereka. Adapun moral sendiri adalah sikap totalitas mereka untuk menjunjung tinggi nilai etik dan nilai kehormatan diri yang termuat dalam tradisi dan kebuayaan mereka.

\section{Analisis Nilai Kearifal Lokal dan Instrumen Pembangunan Madura yang Berkelanjutan}

Salah satukarakteristik pembangunan berkelanjutan (SDGs) sebagaimana telah disinggung $\mathrm{di}$ atas ada pada kecenderungan memperlakuan prinsip pemerataan dan partisipatif. Pemerataan dan partisipatif, selain mengacu pada perwujudan distribusi kebermanfaatan pembangunan secara menyeluruh, juga mengacu pada perwujudan daerah yang mandiri. Yakni, memberi keleluasaan bagi setiap daerah untuk dapat mengembangkan pembangunan mereka berdasarkan aspek-aspek keunggulan alam-sosial mereka. Langkah demikian secara langsung akan mendorong setiap daerah menjadi lebih aktif dalam mengeksplorasi setiap potensi yang ada di wilayah masing-masing. Sehingga setiap daerah memiliki kesempatan cukup besar untuk dapat membangun wilayah mereka berdasarkan corak dan khas alam-sosial masing-masing, tanpa harus menduplikasi, apalagi memaksakan pola pembangunan daerah lain yang sesungguhnya tidak relevan dengan daerah mereka sendiri.
Berkaitan dengan pembangunan Madura, setidaknya ada tiga alasan utama yang mendasari pentingnya penguatan pembangunan Madura yang berkelanjutan melalui nilai keaifan lokal. Pertama, Madura adalah sebuah kawasan kepulauan yang terakit dari banyak pulau. Sebagai daerah kepulauan, sudah pasti jika di setiap daerah memiliki tipologi sosial-alam berbeda. Ada banyak kebudayaan, tradisi, bahasa, dan sekian keanekaragaman lain yang mengidentitas dalam diri masing-masing daerah. Atas dasar kenyataan tersebut, menjadi sulit kemudian - untuk tidak mengatakan mustahil - memberlakukan teknis pelaksanaan pembangunan yang homogen. Fakta keanekaragaman alamsosial di setiap penjuru daerah pulau Madura tidak dapat digeneralisir dalam satu paket instrumen pembangunan yang sama. Artinya, perlu ada terobososanterobosan baru yang dapat menghadirkan cara dan strategi berbeda. Memiliki orientasi pemberdayaan dan pemanfaatan nilai-nilai lokal. Baik itu menyangkut kekayaan alam maupun kekayaan sosial.

Kedua, optimalisasi kebijakan otonomi daerah (otoda). Jika merujuk pada perundangan pembangunan daerah, Tujuan Perencanaan Pembangunan Daerah tidak lain adalah Mewujudkan pembangunan daerah dalam rangka peningkatan dan pemerataan pendapatan masyarakat, kesempatan kerja, lapangan berusaha, meningkatkan akses dan kualitas pelayanan publik dan daya saing daerah. Pembangunan daerah melalui pendekatan pembanguan berkearifan lokal, selain dapat memperluas ruang gerak daerah dalam mengeksplorasi setiap kekayaan yang ada di masingmasing daerah, pun juga dapat memberi 
peran signifikan dalam menguatkan sistem otonomi daerah kita. Jika ruang gerak pengelolaan daerah dibatasi, atau lebih-lebih mengalami intervensi, maka yang demikian bukan saja dapat memperlemah sistem otoda, namun juga aktivitas pembangunan wilayah Madura sebagai sebuah kawasan tritorial yang otonom. Ketiga, nilai lokal sebagai instrumen counter culture. Di tengah masifnya gerak globalisasi yang semakin luas, merupakan suatu yang urgen bagi setiap daaerah untuk dapat mempertahankan kebudayaan dan sekian nilai-nilai kreativitas lokal. Dalam konteks inilah, pembangunan Madura yang berlandaskan pada nilai kearifan lokal bisa digunakan sebagai strategi untuk menjaga, melestarikan, dan memberdayakan segala potensi alamsosial daerah setempat.

Penguatan

pembangunan Madura melalui pendekatan lokalitas sesungguhnya mengandung relevansi kuat dengan semangat pembangunan SDGs. Apalagi sebagaimana dikemukakan di depan, bahwa salah satu prinsip pembangunanSDGsadalahpembangunan yang berorintasi pada penjagaan, pelestarian, dan pemeliharaan kelestarian lingkungan (Bumi). pendekatan demikian, selain dapat berfungsi sebagai pelestarian, pun juga berfungsi besar dalam upaya melakukan counter culture terhadap proyek globalisasi. Dengan pendekatan kearifan lokal, ada harapan agenda pembangunan di berbagai wilayah Madura dapat terhindar dari segala macam praktik eksploitatif. Sehingga tatanan alam-sosial masyarakat Madura akan steril dari praktik-praktik pencemaran lingkungan, polusi udara, dan pengrusakan ekosistem alam secara keseluruhan. Praktik-praktik pengrusakan ekosistem alam inilah yang kemudian dapat kita lihat pada banyak wajah pembangunan daerah berbasis industri Indonesia, khususnya daerah yang tergolong sebagai wilayah metro/ megapolitan.

Dalam perspektif yang lain, instrumen kearifan lokal pembangunan Madura memiliki keunggulan menciptakan sumber perekonomian baru yang mengusung semangat universal. Penguatan sektor kearifan lokal secara langsung akan bersentuhan dengan sistem dan struktur sosial masyarakat. Sehingga setiap dari mereka memiliki kesempatan dan peluang cukup terbuka untuk dapat berpartisipasi secara aktif. Berkearifan lokal artinya memprioritaskan kehadiran dan keterlibatanmasyarakatlokal.Pengelolahan dan pemanfaatan potensi alam diarahkan seluruhnya pada peningkatan mutu hidup masyarakat daerah. Pendekatan ini jelas jauh berbeda dengan daerah industri, yang dalam hubungan kerjanya cenderung eksploitatif dan kapitalis. Dalam konteks pembangunan SDGs, penguatan nilai kearifan lokal adalah terjemahan dari prinsip kemanusiaan dan kemakmuran. Bahwa pembangunan berkelanjutan mensyaratkan pada terwujudnya pembangunan memuatspiritkemanusiaan. Menciptakan realitas pembangunan yang menjunjung tinggi nilai-nilai kemanusiaan, emansipatif, keadaban, dan penghormatan terhadap segala hak.

Jika menengok bunyi konstitusi kita, implementasi pembangunan Madura yang bersandar pada nilai kearifan lokal sesungguhnya cukup terbuka. Peraturan presiden Nomor 59 tahun 2017, tentang Pelaksanaan Pencapaian Tujuan Pembangunan Berkelanjutan menyebutkan bahwa setiap daerah secara 
aktif dapat ikut berpartisipasi dalam proses pembangunan daerah masingmasing, baik itu dalam tahap perencanaan, pembangunan, dan evaluasi. Perpres tersebut mempertegas hak dan keleluasaan daerah Madura mempergunakan hak otonom mereka, melepaskan diri dari belenggu kekakuan sistem pembangunan yang terlampau struktural, sehingga berefek pada produktivitas pertumbuhan dan pengembangan keseluruhan daerah Madura secara mandiri.

Hal paling fundamental dalam proses penguatan pembangunan Madura berkelanjutan melalui kearifan lokal sesungguhnya ada pada sejauh mana pembangunan di Madura dapat menjalin sinergitas dengan konstruksi nilai lokal setempat. Setiap pembangunan Madura harus dapat membangun keselerasan dan keintiman dengan realitas kebudayaan setempat. Dalam kaitan ini, ada dua aspek yang hukumnya wajib diperhatikan dalam proses pembanguan Madura. Yakni aspek religiusitas dan moral. Aspek religiusitas mensyaratkan bahwa agenda pembangunan Madura tidak saja dapat mengusung nilai-nilai religiusitas. Lebih dari itu harus melibatkan para tokoh keagamaan, khususnya Kiai, baik kiai pesantren maupun kiai langgar. Kiai, dalam sistem dan struktur sosial masyarakat Madura memiliki fungsi dan peran sosial strategis dalam mengawal dan mengontrol perubahan sosial masyarakat Madura. Adapun aspek moral mensyaratkan bahwa program penbangunan Madura harus menjunjung tinggi nilai etik, atau paling minimal adalah memuat nilai keseragaman dengan tradisi, kebudayaan, ataupun adat masyarakat setempat.

Seperti kebanyakan hukum pembangunan pada umumnya, pembangunan Madura berkelanjutan berbasis kearifan lokal membutuhkan partisipasi semua pihak. Sinergitas antara masyarakat, organisasi sosial, tokoh masyarakat, dan pemerintah setempat perlu dibangun dan dibentuk sekuat mungkin. Pada batasan ini, pemerintah daerah harus mampu menciptakan terobosan-terobonsan baru yang dapat mendukung. Terutama melalui rancangan kebijakan, program, dan agenda kerja yang berkesesuaian dengan aspek sosiologis Madura. Untuk mencapai itu semua, tentu membutuhkan kepaduan para stake holders, serta adanya tata kelola pemerintahan yang baik, transparan, dan akuntabel.

Belajar dari daerah-daerah lainnya, sepertiBali, Yogyakarta,Surakarta,Solodan lain-lain, kesuksesan mereka membangun daerah melalui pendekatan lokal tidak lepas dari keberhasilan melakukan branding terhadap segala produk dan nilai lokalitas masing-masing. Untuk itu, selain aspek political will dan sinergitas para pemangku kepentingan, juga diperlukan strategi pemasaran daerah Madura yang baik dan efektif. Strategi pemasaran daerah di sini dapat dijalankan dengan memanfaatkan kekuatan teknologi, media massa, dan media sosial. Ada banyak daerah yang berhasil menjalankan agenda pembangunan mereka dengan strategi ini, Banyuwangi, misalnya. Berkenaan dengan pemanfataan teknologi di sini, Richard Florida (1957) menyebutkan bahwa aktivitas promosi daerah (Madura), kaitannya dengan pembangunan Madura berkelanjutan melalui kearifan lokal, hanya akan dapat berhasil manakala memiliki modal tiga (3) T (Leksono, 2014: 2). Tiga moda tersebut adalah: talenta, teknologi, dan terakhir adalah toleransi. 


\section{SIMPULAN}

Dalam upaya membangun Madura berkelanjutan, gagasan penguatan nilai kearifan lokal penting dimunculkan. Pembangunan melalui pendekatan kearifan lokal mensyaratkan pada pembangunan yang tidak saja mengusung visi kemajuan, pertumbuhan, dan pengembangan alam-sosial setempat. Lebih dari itu, mengusung semangat pembangunan yang partisipatif, universal, emansipatif, dan turut memperhatikan masa depan alam-sosial. Memelihara ekosistem, dan menjaga keberlangsungan mahkluk hidup secara keseluruhan.

Visi emansipatif, universalitas, dan partisipatif pembangunan Madura berpeluang besar menciptakan pola pembangunan Madura yang merata dan berkeadilan. Adapun penguatan nilai kearifan lokal dalam instrumen pembangunan Madura, secara langsung akan membuat masyarakat setempat mempunyai peluang dan kesempatan besar untuk dapat mengakses sumbersumber ekonomi. Pendekatan kearifan lokal akan dapat menghadirkan aktivitas dan kegiatan ekonomi yang akan bersentuhan langsung dengan sistem dan struktur masyarakat Madura. Selain itu, melalui pendekatan kearifan lokal, berbagai hal negatif yang berkaitan dengan pembangunan akan lebih memungkinkan teratasi. Misal, pencemaran lingkungan, pengrusakan pada ekosistem alam, praktik eksploitatif sember daya alam, dan segala bentuk kapitalisme lainnya.

Untuk dapat mewujudkan gagasan pembangunan Madura berkelanjutan melalui penguatan nilai-nilai kearifan lokal, maka agenda pembangunan Madura harus mendasarkan pada kultur dan sistem sosial masyarakat setempat. Dalam kaitan ini, ada dua hal yang perlu diperhatikan: 1) aspek religiusitas, aspek ini mensyaratkan bahwa pembangunan di Madura harus dapat menjalin keselerasan dengan nilai dan simbol keyakinan yang berlaku di kalangan masyarakat setempat. Aspek ini bukan saja dilakukan secara kultural, namun juga struktural. Yakni, melibatkan tokoh-tokoh penting keagamaan yang memiliki pengaruhbesar secara hierarki atau struktur keagamaan, seperti halnya keberadaan Kiai; 2) aspek moralitas. Aspek ini mensyaratkan bahwa pembangunan Madura harus mengusung semangat etik dan perbaikan moral. Aspek ini harus diperhatikan, mengingat selama ini bangunan sistem dan struktur sosial masyarakat Madura berlandaskan kuat pada tradisi dan adat. Dalam banyak kesempatan, adat, tradisi, dan kebudayaan di kalangan msayarakat Madura merupakan standar moral tinggi, yang jika itu dilanggar akan dengan mudah memicu pertentangan.

\section{DAFTAR PUSTAKA}

2001. Kamus Besar Bahasa Indonesia. Jakarta: Balai Pustaka.

Abdullah, Irwan, dkk (ed.). 2008. Agama Dan Kearifan Lokal Dalam Tantangan Global. Yogyakarta: Pustaka Pelajar.

Anggraini, Amelia, 2017. Indonesia dan SDGS, http://www.mediaindonesia. com/, 27 Sep 2017.

Arafah, N. 2002. Pengetahuan Lokal Suku Moronene Dalam Sistem Pertanian Di Sulawesi Tenggara. Program Pascasarjana Institut Pertanian Bogor.

Departemen Pendidikan dan Kebudayaan. 1999. Kamus Besar bahasa Indonesia (Edisi Kedua). Balai Pustaka: Jakarta.

Erwandari, Nelti. 2017. Implementasi Sustainable Development Goals (SDGs) 
Dalam Meningkatkan Ketahanan Pangan Di Provinsi Riau. Jurnal Ilmu Hubungan Internasional, Vol. 5 (3).

Fitria, Tira Nur. 2016. Kontribusi Ekonomi Islam Dalam Pembangunan Ekonomi Nasional. Jurnal Ilmiah Ekonomi Islam, Vol. 02 (03)

Hendriyani, Chandra. 2016. Contradictions Economic Growth \& Investor Exit In Indonesia. Jurnal AdBispreneur, Vol. I (1).

Hidayat, Medhy Aginta. 2012. Menggugat Modernisme: Mengenali Rentang Pemikiran Postdernisme Jean Baudrillad. Yogyakarta: Jalasutra.

Ishartono dan Santoso Tri Raharjo, Sustainable Development Goals (SDGs) dan Pengentasan Kemiskinan. Share: Social Work Jurnal, Vol VI (2).

Iwan Nugroho dan r. Dahuri. 2004. Pembangunan Wilayah Perspektif Ekonomi Sosial dan Lingkungan. Pustaka LP3S Indonesia, Anggota Ikapi.

Iyan, Rita Yani. 2012. Peran Hukum Dalam Pembangunan Ekonomi. Jurnal Sosial Ekonomi Pembangunan, Vol. II (5).

Jafar, 2017. Solidaritas Imigran Madura Di Perantauan Desa Jemparing Kecamatan Longikis Kabupaten Paser. E-Journal Sosiatri-Sosiologi, Vol.5 (1).

Jawa pos, 2017, https://www.jawapos. com/, diakses pada 29/13/2018.

Jemadu, Aleksius. 2003. Pembangunan Dan Modernisasi: Implikasinya Terhadap Tatanan Ekologi Dan Sosial. Jurnal JAP, Vol. I (2).

Leksono, Afif dan Purbayu Budi Santosa. 2014. Faktor-Faktor Yang Mempengaruhi Pendapatan Industri Kreatif Di Indonesia (Tahun 2002-2008). Journal of economic, Vol. 3 (1).

Martin, Roderick. 1995. Sosiologi Kekuasaan. Jakarta: Rajawali Press.

Nur Hayati, Beti dan Muhammad Arif Fahrudin Alfana. 2016. Kebijakan Kependudukan Di Kabupaten Sleman Pasca Berakhirnya MDGS. Natapraja;
Jurnal Kajian Ilmu Administrasi Negara, Vol.4 (2).

Oktaviani, Tia. Dkk. 2011. Kearifan Lokal Dalam Pengelolaan Sumberdaya Air Di Kampung Kuta, Local Wisdom of Water Resource Management in Kampung Kuta. Jurnal Transdisiplin Sosiologi, Komunikasi, dan Ekologi Manusia, Vol. 4, (3).

Pasaribu, Rowland B. F. T.th. Teori-teori pembangunan. Tanpa penerbit.

Penuluh, Sekar dan Meila Riskia Fitri. 2016. Perkembangan Pelaksanaan Sustainable Development Goals (Sdgs) Di Indonesia September 2015-September 2016. Paper dalam International NGO Forum On Indonesian Development.

Prasetya, Dion Maulana. 2016. Geopolitik Bantuan Luar Negeri Dari Perang Dingin Sampai Globalisasi. Jurnal Sospol, vol. II (1).

Rahadian, A.h. 2016. Strategi Pembangunan Berkelanjutan. Jurnal stiami, Vol. III (1).

Ruslin, Ismah Tita. 2012. Relasi EkonomiPolitik Dalam Perspektif Dependencia. Jurnal Sulesana, Vol.7 (2).

Restiyanto, Dumadi Tri. 2017. Kegagalan Pembangunan Ekonomi Indonesia Akibat Terperangkap Kegagalan Pendekatan Teori Ekonomi Pembangunan. Akses: Jurnal Ekonomi Dan Bisnis, Vol. 1 (2).

Sadi, A. Sulaiman. 2011) Kearifan Lokal Dalam Sastra Madura Dan Aplikasinya Dalam Kehidupan Sehari-Hari. Jurnal Okara, Vol. 88 (1).

Sartini. 2004. Menggali Kearifan Lokal Nusantara Sebuah Kajian Filsafati. Jurnal Filsafat, Vol. 37 (2).

Sari, Ita Puspita. 2016. Implementasi Pembangunan Partisipatif, Studi Kasus Di Kelurahan Andowia Kabupaten Konawe Utara. Jurnal ekonomi (je), Vol. 1 (1).

Subarkah, Muhammad, Pancasila, Konflik Sosial, Balkanisasi: Fiksi Negara Bubar?. Republika, http://www.republika. co.id/. Diakses pada 27 Maret 2018. 
Susanto, Edi. 2007. Revitalisasi Nilai Luhur Tradisi Lokal Madura. Jurnal Karsa, Vol. xii (2).

Sulistyastuti, Dyah Ratih. 2007. Pembangunan Pendidikan dan MDGs Di Indonesia; Sebuah Refleksi. Kritis. Jurnal Kependudukan Indonesia Vol. II (2).

Surtikanti,. 2013. Permasalahan Otonomi Daerah Ditinjau Dari Aspek Perimbangan Keuangan Pemerintah Pusat Dan Daerah. Majalah Ilmiah Unikom, Vol. II (1).

Sulistyo, Budi, dkk. 2010. MDGs Sebentar Lagi. Jakarta: Penerbit Buku Kompas.

Sztompka, Pior. 2007. Sosiologi Perubahan Sosial. Jakarta: Penanda Media Group.

Taufiqurrahman. 2007. Identitas Budaya Madura, Jurnal Karsa, Vol. xi (1).

Tikson, Deddy T. 2005. Keterbelakangan $\mathcal{E}$ Ketergantungan: Teori Pembangunan Di Indonesia, Malaysia, dan Thailand. Bandung: Alfabeta.
Utomo, Budi. Tantangan Pencapaian Millenium Development Goals (MDGS) Bidang Kesehatan Di Indonesia. Jurnal Kesehatan Masyarakat Nasional, Vol. 1 (5).

Wiyata, A. Latief. 2003. Madura Yang Patuh? Kajian Antropologi Mengenai Budaya Madura,. Jakarta: Ceric-Fisip UI.

Wirawan, Ricky, Mardiyono dan Ratih Nurpratiwi. 2015. Partisipasi Masyarakat Dalam Perencanaan Pembangunan Daerah. JISIP: Jurnal Ilmu Sosial dan Ilmu Politik Vol. 4 (2).

Wirartha, I Made. 2006. Metodologi Penetilian Sosial Ekonomi. Yogyakarta: C.V Andi Offset.

Yamin, Moh dan Darsyah dan Rochdi Wasono. 2013. Pendugaan Tingkat Kemiskinan Di Kabupaten Sumenep Dengan Pendekatan Sae, Tanpa Penerbit. 